MATEC Web of Conferences 53, 01023 (2016)

DOI: $10.1051 /$ matecconf/20165301023

(C) Owned by the authors, published by EDP Sciences, 2016

\title{
Quality Improvement of Concrete Articles
}

\author{
Larisa Svatovskaya ${ }^{1}$, Anastasiya Sychova ${ }^{1}$, Maxim Sychov ${ }^{2, a}$, Vladimir Okrepilov ${ }^{3}$ \\ ${ }^{1}$ Petersburg State Transport University, St.Petersburg, Russia \\ ${ }^{2}$ Saint Petersburg State Technological Institute, St.Petersburg, Russia \\ ${ }^{3}$ State Regional Centre for Standardization, Metrology and Testing in St. Petersburg and Leningrad Region (State \\ Centre "Test-St. Petersburg"), Kurlyandskaya, 1, St. Petersburg, 190103, Russia
}

\begin{abstract}
In the paper it is shown that quality of concrete articles and structures may be significantly improved by silica sol solution absorption. Improvements include increase of compressive strength, resistance to low temperatures, coefficient of constructive quality, decrease of water sorption, contraction. The reason of improvement is discussed.
\end{abstract}

\section{Introduction}

It is well known that surface properties of construction materials, including acid-basic ones are very important [1-5]. The main idea of the paper is the possibility of improvement of quality of concrete articles by means of saturation and modification of their surface with silica sol solution. Due to the presence of capillary pores concrete articles and structures possess ability to soak silica sol solution. After soaking process silica sol appears in cement based materials' pores and may participate in the reaction:

$$
5 \mathrm{Ca}(\mathrm{OH})_{2}+6\left(\mathrm{SiO}_{2} \cdot \mathrm{H}_{2} \mathrm{O}\right)=5 \mathrm{CaO} \cdot 6 \mathrm{SiO}_{2} \cdot 5,5 \mathrm{H}_{2} \mathrm{O}+5,5 \mathrm{H}_{2} \mathrm{O}, \Delta \mathrm{G}_{298}^{0}=-584.8 \mathrm{~kJ}
$$

Reaction (1) is characterized by negative value of Gibbs energy, therefore new calcium silicates are formed, which is good for improvement of the construction article quality [6-12]. Due to presence of certain amount of capillary pores, their sizes and peculiarities of reaction (1), each cement based article can intake only certain limited quantity of silica sol. Thus we introduce new parameter to characterize concrete articles' ability to intake silica sol - absorption capacity $\mathrm{C}(\mathrm{kg} / \mathrm{m} 3)$, mass of silica sol absorbed by unit volume of article.

\section{Experiment, results and discussion}

According to the preliminary experiment [8] it was chosen to perform experiments on quality improvement of construction articles using samplers of foam concrete with the following average density values D: $0.4 ; 0.5$ and $0.6 \mathrm{Ton} / \mathrm{m} 3$. For the modification of samples we used $1.5 \%$ silica sol solution. Characteristics of solution: $\mathrm{pH} \sim 9$, density of solution $-1.02 \mathrm{~g} / \mathrm{cm} 3$, particle diameter of silica sol dispersions $-12 \mathrm{~nm}$.

\footnotetext{
${ }^{\mathrm{a}}$ Corresponding author : msychov@yahoo.com
} 
Samples were saturated by the silica sol solution on the third day of hardening process and then were examined. The process of saturating with silica was described using suggested above new parameter - absorption capacity, $\mathrm{C}, \mathrm{kg} / \mathrm{m} 3$, calculated according to equation (2).

$$
C=\frac{m_{1}-m_{2}}{V}, k g / m^{3}
$$

where between $\mathrm{m} 1$ and $\mathrm{m} 2$ are masses of sample before and after the modification process, $\mathrm{kg} ; \mathrm{V}$ - volume of sample, $\mathrm{m} 3$.

After that modified sample of concrete article was tested according to common protocols such as water absorption, compressive strength, resistance to low temperatures, contraction and coefficient of constructive quality. Overall quality of cement articles was characterized by the value of specific compressive strength $[10,13,14]$.

The main results are shown in the Table 1. One can see that quality of modified articles was improved and their properties are superior compering to ones of article without modification. Some two-fold increase of main characteristics of concrete articles was achieved by modification. Explanation of such kind of quality improvement is the healing of the pore structure and decrease of total volume of pores by means of silica sol saturation and occurrence of reaction (1). Parameter C reflects absorption of silica sol and formation of new phases in the pore space of articles according to the reaction (1). From the data of table 1 it is clear that value of parameter $\mathrm{C}$ increases with the rise of density of concrete article [15-18].

Table 1. Improvement of characteristics of foam concrete samples after modification.

\begin{tabular}{|c|c|c|c|c|c|c|c|c|c|c|c|}
\hline \multirow{3}{*}{$\begin{array}{c}\mathrm{D}, \\
\text { Ton } / \mathrm{m} 3\end{array}$} & \multirow{3}{*}{$\underset{\mathrm{kg} / \mathrm{m} 3}{\mathrm{C}}$} & \multicolumn{10}{|c|}{ Improvement of sample quality } \\
\hline & & \multicolumn{2}{|c|}{$\sigma, \mathrm{MPa}$} & \multicolumn{2}{|c|}{$\begin{array}{c}\text { Water absorption, } \\
\%\end{array}$} & \multicolumn{2}{|c|}{$\begin{array}{c}\text { Resistance to } \\
\text { low } \\
\text { temperatures, } \\
\text { cycles }\end{array}$} & \multicolumn{2}{|c|}{$\begin{array}{c}\text { Contraction, } \\
\mathrm{mm} / \mathrm{m}\end{array}$} & \multicolumn{2}{|c|}{$\begin{array}{l}\text { Specific } \\
\text { strength, } \\
\sigma / D\end{array}$} \\
\hline & & 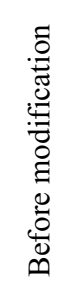 & 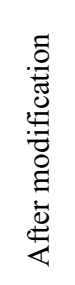 & 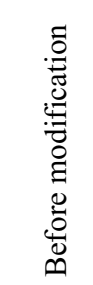 & 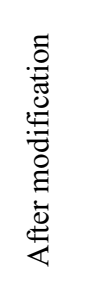 & 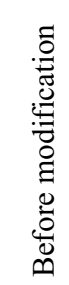 & 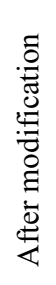 & 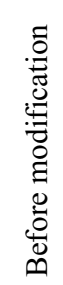 & 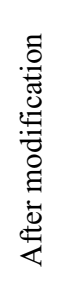 & 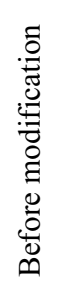 & 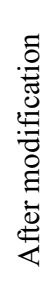 \\
\hline 0.4 & 0.24 & 0.5 & 1.04 & 24.2 & 15.0 & 15 & 25 & 4.2 & 1.3 & 1 & 2 \\
\hline 0.5 & 0.30 & 1.2 & 2.08 & 22.8 & 11.2 & 15 & 35 & 3.5 & 1.1 & 2 & 4 \\
\hline 0.6 & 0.36 & 1.56 & 2.98 & 21.3 & 9.3 & 25 & 50 & 2.9 & 0.9 & 2.6 & 5 \\
\hline
\end{tabular}

In the Table 2 one can see results of the experiment on modification of concrete samples using different concentrations of silica sol. The level of the improvement of characteristics of modified heavy concrete samples is lower comparing to that of foam concrete, nevertheless $40 \ldots 60 \%$ increase of strength was achieved $[19,20]$. 
The main reason for the improvement of properties is the reaction (1) providing formation of additional amount of calcium silicates. That amount may be calculated taking into account reaction (1) and values of absorption capacity $\mathrm{C}$. Examples of such kind of calculations are presented in the Table 3.

Table 2. Increase of strength of concrete samples

\begin{tabular}{|c|c|c|c|c|c|c|c|c|}
\hline \multirow{2}{*}{$\begin{array}{c}\mathrm{D}, \\
\text { Ton/m3 }\end{array}$} & \multirow{2}{*}{$\begin{array}{c}\text { Days } \\
\text { of hardening }\end{array}$} & \multicolumn{2}{|c|}{$\begin{array}{l}\text { Strength of sample } \\
\text { before modification, } \\
\mathrm{MPa}\end{array}$} & \multirow{2}{*}{ 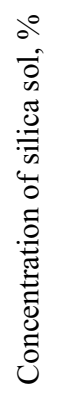 } & \multicolumn{2}{|c|}{$\begin{array}{l}\text { Strength of sample } \\
\text { after after } \\
\text { modification, } \mathrm{MPa}\end{array}$} & \multicolumn{2}{|c|}{$\begin{array}{c}\text { Increase of strength } \\
\text { after modification, } \\
\%\end{array}$} \\
\hline & & 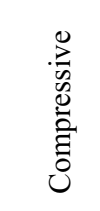 & 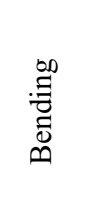 & & 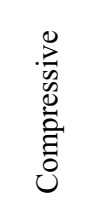 & 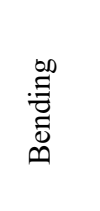 & 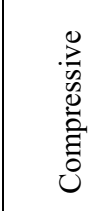 & 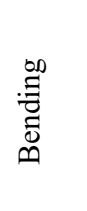 \\
\hline 2.0 & 10 , heat treatment & 14.97 & 3.92 & 10 & 24.38 & 5.53 & 63 & 41 \\
\hline 2.0 & $\begin{array}{c}28, \text { normal } \\
\text { hardening (n.h.) }\end{array}$ & 14.08 & 4.23 & 5 & 20.65 & 5.95 & 47 & 41 \\
\hline 0.6 & 28 n.h. & 1.07 & 0.86 & 15 & 1.89 & 1.23 & 74 & 43 \\
\hline 0.5 & 28 n.h. & 0.93 & 0.73 & 15 & 1.65 & 1.14 & 78 & 56 \\
\hline
\end{tabular}

Table 3. Hydrate calcium silicates in concrete and absorption capacity

\begin{tabular}{|c|c|c|}
\hline $\begin{array}{c}\text { Average density of concrete } \\
\text { samples D, Ton } / \mathrm{m} 3\end{array}$ & $\begin{array}{c}\text { Absorption capacity C, } \\
\mathrm{kg} / \mathrm{m} 3\end{array}$ & $\begin{array}{c}\text { Calculated quantity of calcium silicates, } \\
\text { formed according to reaction }(1), \mathrm{kg} / \mathrm{m} 3\end{array}$ \\
\hline 0.4 & 0.38 & 0.60 \\
\hline 0.5 & 0.47 & 0.74 \\
\hline 0.6 & 0.57 & 0.90 \\
\hline 2.0 & 0.76 & 1.20 \\
\hline
\end{tabular}

\section{Conclusions}

It was shown that such characteristics of foam concrete and heavy concrete articles as compressive strength, water absorption, resistance to low temperatures and contraction may the significantly improved by modification with silica sol solutions. Due to the presence of capillary pores intake of solution takes place resulting in formation of new silicate phases and healing of pores.

\section{References}

1. M.M. Sychov, Applied Surface Science, 244, 461-464 (2005)

2. M.M. Sychov, Journal of the SID, 11, 33-38 (2003) 
3. O.A. Cheremisina, M.M. Sychev, S.V. Myakin, V.G. Korsakov, V.V. Popov, N.Y. Artsutanov, Russian Journal of Physical Chemistry, 76 (9), 1472-1475 (2002)

4. S.V. Myakin, V.G. Korsakov, T.I. Panova, E.A. Sosnov, Yu.C. Fomchenkova, M. M. Sychov, O.A. Shilova, Glass Physics and Chemistry, 37(6), 624-628 (2011)

5. V. G. Korsakov, S. A. Alekseev, M. M. Sychev, M. N. Tsvetkova, E. V. Komarov, B. Lee, S. V. Myakin, and I. V. Vasil'eva, Russian Journal of Applied Chemistry, 80(11), 1931-1935 (2007)

6. L.B. Svatovskaya, M.M. Sychov, Aktivirovannoye tverdeniye tsementa [Activated hardening of cement], (Leningrad, Building-published house, 1983)

7. L.B. Svatovskaya, L.L. Maslennikova and others Thermodynamical and electronic aspects of the building materiel properties, (St.Peterburg, Building published house, 2004)

8. M. Hammady, The method of the modification of the concrete by by means of nanosolution. www.spgasu.ru

9. P. Perrot P, A to $Z$ of Thermodynamics (Oxford University Press. 2004)

10. W. Greiner, L. Neisse, H. Stocker, Thermodynamics and statistical mechanics (Springer-Verlag, 1995)

11. J. Ćetković, S. Rutešić, M. Zarković, M. Knežević, N. Vatin, Procedia Engineering, 117 (1), 780 790 (2015).

12. S. Rutešić, J. Ćetković, M. Žarcković, M. Knežević, N. Vatin, Procedia Engineering, 117 (1), 905 - 915 (2015).

13. S. Rutešić, J. Ćetković, M. Knežević, M. Žarcković, N. Vatin, Procedia Engineering, 117 (1), 642 - 650 (2015).

14. N. Gubeljak, J. Predan, D. Kozak, J. Tuma, B. Kovačič, P. Konjatić, J. Sertić, Strojarstvo, 51 (4), 263-271 (2009)

15. B. Kovačič, R. Kamnik, M. Premrov, N. Gubeljak, J. Predan, Z. Tišma, Strojniski Vestnik/Journal of Mechanical Engineering, 54 (5), 364-371 (2008)

16. B. Kovačič, R. Kamnik, International Journal for Engineering Modelling, 20 (1-4), 77-84 (2007).

17. M.M. Sychov, N.V. Zakharova, S.V. Mjakin, Ceramics International, 39, 6821-6826 (2013)

18. V.V. Bakhmet'ev, M.M. Sychev, V.G. Korsakov, Russian Journal of Applied Chemistry, 83(11), 1903-1910 (2010)

19. B. Kovačič, B. Supej, (2004) Geodetski Vestnik, 48 (1), 40-49 (2004)

20. B . Kovačič, B. Geodetski Vestnik, 48 (1), 32-39 (2004). 